\title{
Akses UMKM Terhadap Pembiayaan Mikro Syariah dan Dampaknya Terhadap Perkembangan Usaha : Kasus BMT Tadbiirul Ummah, Kabupaten Bogor
}

\section{The Access of MSME towards Islamic Microfinancing and Its Impact on Business Development: A Case of BMT Tadbiirul Ummah, Bogor}

\author{
Lukytawati Anggraeni, Herdiana Puspitasari, Salahuddin El Ayubbi, dan Ranti Wiliasih \\ Departemen Ilmu Ekonomi, Fakultas Ekonomi dan Manajemen Institut Pertanian Bogor
}

\begin{abstract}
Micro, Small and Medium Enterprises (MSMEs) have a big contribution for Indonesia's gross domestic product and employment. Most MSMEs face capital constraints and limited access to formal financial institutions. Baitul Maal Wat Tamwil (BMT), which is one of the Islamic microfinance institutions, can be a solution to capital constraints faced by MSMEs. The study aims to analyze the MSME access to get the financing and the impact of BMT to their business development. The primary data is obtained from interviewing 45 respondents, i.e 30 respondents who receive funding from the BMT and 15 controlled respondents who do not receive funding in Bogor. MSME access to the BMT Islamic financing is analyzed by logistic regression logit model while the method used is multiple linear regression of Ordinary Least Square (OLS) in order to analyze the impact of BMT on the development of business. Logit regression results indicate that dummy business type, age, business turnover and deposits dummy, are the factors influencing MSME access to BMT financing. BMT financing has increased the MSME profit by 6.21 percent with an average of $\mathrm{Rp} 79.12$ million to $\mathrm{Rp}$ 84.03 million per year. Based on the results of multiple linear regression of OLS, BMT financing has positive and significant impact on the change in business profits.
\end{abstract}

Keywords: BMT, Logit, OLS, Islamic microfinancing, MSME

\begin{abstract}
Abstrak. Usaha Mikro, Kecil dan Menengah (UMKM) memiliki peranan cukup besar bagi pendapatan domestik bruto Indonesia dan penyerapan tenaga kerja. Namun sebagian besar UMKM menghadapi kendala permodalan dan keterbatasan akses pada lembaga keuangan formal. Baitul Maal Wat Tamwil (BMT) merupakan salah satu lembaga keuangan mikro syariah yang dapat menjadi solusi kendala permodalan pada UMKM. Studi bertujuan untuk menganalisis akses UMKM terhadap pembiayaan syariah BMT dan dampaknya terhadap perkembangan usaha. Data primer diperoleh dari hasil wawancara 45 responden, yaitu 30 responden yang mendapatkan pembiayaan dari BMT dan 15 responden kontrol yang tidak mendapatkan pembiayaan di Kabupaten Bogor. Akses UMKM terhadap pembiayaan syariah BMT dianalisis dengan metode regresi logistik model logit sedangkan metode regresi linear berganda Ordinary Least Square (OLS) untuk menganalisis dampak pembiayaan syariah BMT terhadap perkembangan usaha. Hasil regresi logit menunjukkan dummy jenis usaha, umur, omset usaha dan dummy akses simpanan merupakan faktor-faktor yang mempengaruhi akses UMKM terhadap pembiayaan BMT. Pembiayaan mikro syariah BMT yang diberikan mampu meningkatkan keuntungan UMKM sebesar 6,21 persen dari keuntungan usaha rata-rata Rp 79,12 juta menjadi Rp 84,03 juta per tahun. Berdasarkan hasil regresi linear berganda OLS, pembiayaan syariah BMT berpengaruh positif dan signifikan terhadap perubahan keuntungan usaha.
\end{abstract}

Kata kunci: BMT, Logit, OLS, Pembiayaan Mikro Syariah, UMKM 


\section{PENDAHULUAN}

Usaha Mikro, Kecil dan Menengah (UMKM) di Indonesia mempunyai peranan signifikan terhadap perekonomian nasional khususnya Produk Domestik Bruto (PDB), penyerapan tenaga kerja serta pengentasan kemiskinan. Kontribusi UMKM terhadap PDB nasional tahun 2010 tercatat sebesar 3,46 milyar rupiah dan mampu menyerap tenaga kerja sebesar 99,40 juta orang atau 97,22 persen dari angkatan kerja. Jumlah UMKM mengalami peningkatan sebesar 2,01 persen pada periode tahun 2009-2010, yaitu mencapai 53,82 juta unit usaha dimana 98,85 persen merupakan usaha mikro. Terlepas peranan penting UMKM terhadap perekonomian, sebagian besar menghadapi kendala permodalan. UMKM yang telah memiliki akses kredit pada perbankan hanya sekitar 37,36 persen atau 19,1 juta unit usaha (Kemenkop, 2011).

Baitul Maal wat Tamwil (BMT) merupakan salah satu lembaga keuangan mikro syariah yang dapat mendukung permodalan UMKM. Hal tersebut mengingat layanan keuangan mikro syariah BMT relatif dapat lebih mudah diakses sebagian besar UMKM yang unbankable. Pembiayaan syariah memberikan kelebihan yang tidak dimiliki oleh lembaga konvensional karena tidak adanya sistem bunga yang dapat membebani UMKM (beban bunga yang terus bertambah).

Kinerja penyaluran pembiayaan mikro syariah dari BMT semakin meningkat. Berdasarkan data BI pada bulan Oktober 2004 jumlah BMT sebanyak 3.038 unit dengan 1.200.000 nasabah dengan total pinjaman 157 miliar dan total simpanan 209 miliar. Kerjasama BMT dengan Kementrian Koperasi Usaha Kecil dan Menengah pada tahun 2003 melalui program dana bergulir syari'ah telah menyalurkan pembiayaan pada 127 BMT dengan nilai Rp. 6,35 milyar. Sedangkan kredit macetnya (Non Perfomong Loan) juga kecil, yaitu $2 \%$. Implikasi dari keberhasilan tersebut, pada tahun 2005 dana untuk program ditambah menjadi Rp. 53 milyar yang diberikan kepada 256 BMT di seluruh Indonesia.

Studi terkait peranan BMT dalam Potensi Kabupaten Bogor didominasi oleh industri kecil. Hal ini terbukti dengan banyaknya penerbitan Surat Izin Usaha Perdagangan (SIUP) dan peningkatan jumlah UMKM sebanyak 1.300 unit per Desember 2011 dibanding tahun sebelumnya (Dinas Koperasi UKM Perindustrian dan Perdagangan Kabupaten Bogor, 2012). Penelitian tentang BMT selama ini hanya fokus mengkaji faktor-faktor yang mempengaruhi pengambilan pembiayaan dan efektivitasnya (Aryati, 2006; Kurnialestari, 2007; Oktavi, 2009). Oleh karena itu, perlu dikaji mengenai akses UMKM terhadap pembiayaan mikro syariah BMT serta dampaknya terhadap perkembangan usaha.

Berdasarkan permasalahan tersebut, maka tujuan dari penelitian ini adalah sebagai berikut:

1. Mendeskripsikan akses UMKM pada lembaga keuangan;

2. Menganalisis faktor-faktor yang mempengaruhi akses UMKM terhadap pembiayaan syariah BMT;

3. Menganalisis dampak pembiayaan syariah BMT terhadap perkembangan usaha UMKM. 


\section{TINJAUAN PUSTAKA}

\subsection{Kredit Mikro}

Berdasarkan Menteri Koordinasi Kesejahteraan Rakyat dan Gubernur Bank Indonesia tentang Penanggulangan Kemiskinan Melalui Pemberdayaan Pembangunan Usaha Mikro Kecil dan Menengah. (No.11/KEP/MENKO/KESRA/IV/2002-No.4/2/KEP.GBI/2002 tanggal 22 April 2002), definisi kredit mikro adalah kredit yang diberikan pada nasabah usaha mikro baik langsung maupun tidak langsung, yang dimiliki dan dijalankan oleh penduduk miskin dengan kriteria penduduk miskin menurut BPS dengan plafon maksimal Rp 50 juta.

\subsection{Usaha Mikro, Kecil dan Menengah (UMKM)}

Usaha (mikro) kecil menengah di Indonesia merupakan bagian penting dari sistem perekonomian nasional karena berperan untuk mempercepat pemerataan pertumbuhan ekonomi melalui misi penyediaan lapangan usaha dan lapangan kerja, peningkatan pendapatan masyarakat dan ikut berperan dalam meningkatkan perolehan devisa serta memperkokoh struktur industri nasional. Definisi UMKM diatur dalam Undang-Undang Republik Indonesia Nomor 20 Tahun 2008 tentang UMKM, dinyatakan bahwa usaha mikro adalah usaha produktif milik orang perseorangan atau badan usaha perseorangan yang memiliki nilai aset paling banyak Rp 50 juta atau dengan hasil penjualan tahunan paling besar Rp 300 juta. Usaha kecil adalah usaha ekonomi produktif yang dilakukan oleh orang perseorangan atau badan usaha yang bukan anak perusahaan atau bukan cabang perusahaan yang memiliki nilai aset lebih dari Rp 50 juta sampai paling banyak Rp 500 juta atau memiliki hasil penjualan tahunan lebih dari Rp 300 juta hingga maksimum Rp 2,5 milyar. Sedangkan usaha menengah adalah usaha ekonomi produktif dengan nilai kekayaan bersih lebih dari Rp 500 juta hingga paling banyak Rp 10 milyar atau memiliki hasil penjualan tahunan di atas Rp 2,5 milyar sampai Rp 50 milyar.

\subsection{Baitul Maal wa Tamwil (BMT)}

Lembaga Keuangan Mikro di Indonesia berdasarkan tipenya secara umum dibagi menjadi tiga yaitu: (1) lembaga formal merupakan sektor keuangan formal yang diatur oleh Undangundang perbankan dan diawasi oleh Bank Indonesia, misalnya Bank Rakyat Indonesia (BRI), Bank Perkreditan Rakyat (BPR); (2) lembaga semi formal merupakan sektor keuangan semi formal yang bukan menjadi subjek dari Undang-undang perbankan tetapi tetap diatur dan diawasi oleh pemerintah selain Bank Indonesia, misalnya Badan Kredit Desa (BKD), Koperasi Unit Desa (KUD), Baitul Maal wat Tamwil (BMT); dan (3) lembaga informal, misalnya rentenir, bank keliling, perjanjian keuangan yang menyangkut lahan, tenaga kerja dan pertukaran barang.

BMT adalah lembaga swadaya masyarakat yang didirikan dan dikembangkan oleh masyarakat terutama pada awal berdiri, biasanya dilakukan dengan menggunakan sumber daya termasuk dana atau modal dari masyarakat setempat itu sendiri (Rizky, 2007). BMT memiliki beberapa kelebihan. Pertama, dalam BMT terkandung dua kepentingan yang saling menunjang yaitu kepentingan sosial dan kepentingan bisnis. Kepentingan sosial direpresentasikan oleh baitul maal dan kepentingan bisnis direpresentasikan oleh baitul tamwil. Kedua, sistem operasi BMT mengacu pada ketentuan-ketentuan Islam, bukan menggunakan sistem bunga seperti pada lembaga keuangan konvensional. Ketiga, pemimpin dan pengurus BMT bertindak aktif, proaktif, dinamis, tidak menunggu tetapi menjemput calon anggota penyimpan atau peminjam. 


\subsection{Tinjauan Pembiayaan pada Ekonomi Syariah}

Kata pinjam-meminjam dalam ekonomi syariah kurang tepat digunakan disebabkan oleh dua hal. Pertama, pinjaman merupakan salah satu metode hubungan finansial dalam Islam. Kedua, dalam Islam, pinjam-meminjam adalah akad sosial bukan akad komersial. Pembiayaan atau financing adalah pendanaan yang diberikan oleh suatu pihak kepada pihak lain untuk mendukung investasi yang telah direncanakan, baik dilakukan sendiri maupun lembaga.

\subsection{Produk Pembiayaan Syariah}

Ada beberapa produk pembiayaan syariah yang ditawarkan oleh lembaga keuangan baik bank maupun non bank antara lain: produk simpanan (al-wadi'ah); produk bagi hasil (syirkah) yang terdiri dari musyarakah dan mudharabah; produk jual beli (ba'i) yang terdiri dari murabahah, salam dan istishna serta produk sewa (ijarah).

\subsection{Penelitian Terdahulu}

Oktavi (2009) meneliti mengenai faktor-faktor yang mempengaruhi pengambilan pembiayaan dan efektivitas pembiayaan usaha kecil pada Lembaga Keuangan Mikro Syariah yaitu BMT Bina Umat Sejahtera (BUS), Lasem, Jawa Tengah. Hasil penelitian ini menunjukkan bahwa variabel yang signifikan terhadap pengambilan pembiayaan adalah biaya peminjaman, jangka waktu angsuran dan adanya agunan dengan variabel yang berpengaruh paling besar adalah biaya peminjaman. Berdasarkan hasil penilaian responden mengenai prosedur pembiayaan, pembiayaan usaha kecil BMT BUS ini dapat dikategorikan cukup efektif. Tetapi jika dinilai dari dampak pembiayaan terhadap pendapatan usaha dan keuntungan usaha, tujuan pembiayaan belum sepenuhnya tercapai.

Supriatna (2008) fokus terhadap aksesibilitas petani kecil pada sumber kredit studi kasus petani padi di Nusa Tenggara Barat. Hasil penelitian ini menunjukkan bahwa 80 persen petani menggunakan modal sendiri juga melakukan pinjaman kredit dan hanya 20 persen menggunakan modal sendiri. Akses petani terhadap lembaga keuangan formal masih kurang, dikarenakan petani tidak memiliki agunan sertifikat tanah, selain itu petani juga tidak memenuhi syarat cara pembayaran bulanan. Hal ini tidak sesuai dengan karakteristik usahatani yang penerimaannya musiman. Akibatnya akses petani terhadap lembaga keuangan formal masih kurang.

Widyaningrum (2002) melakukan kajian terhadap BMT Dampingan Yayasan Peramu Bogor. Hasil studi menunjukkan ada empat kelebihan BMTdibandingkan dengan lembaga keuangan lainnya, yaitu: prosedur yang lebih mudah, persyaratan lebih ringan, pelayanan cepat dan penerapan model "jemput bola" yang memudahkan pelanggan. Kelebihan ini sangat memudahkan bagi pengusaha kecil sehingga dapat disimpulkan bahwa alasan utama UKM menerima kehadiran BMT bukan karena BMT menerapkan sistem syariah dalam operasionalnya, namun lebih kepada kemudahan-kemudahan tadi. Bahwa syariah tidak menjadi alasan memilih BMT, karena dari studi ini diketahui mayoritas mitra BMT belum terlalu empat puluh satu persen menyatakan hanya tahu sedikit tentang sistem syariah, empat puluh tujuh persen menyatakan tidak tahu, dan hanya 12 persen yang menyatakan sudah tahu.

Studi Hidayati (2009) menunjukkan bahwa faktor-faktor yang mempengaruhi permintaan pembiayaan lembaga keuangan syariah adalah tingkat pendidikan, pendapatan dan persepsi anggota terhadap pelayanan BMT terhadap permintaan pembiayaan. Sembilan puluh delapan nasabah pembiayaan BMT menjadi sampel penelitian. Hasil analisis menunjukkan bahwa variabel tingkat pendidikan, tingkat pendapatan dan persepsi anggota terhadap BMT berpengaruh terhadap permintaan pembiayaan. Secara umum, permintaan pembiayaan di BMT Safinah ini diperuntukkan untuk modal kerja dengan nilai Rp 100.000- 500.000. 


\subsection{Kerangka Pemikiran}

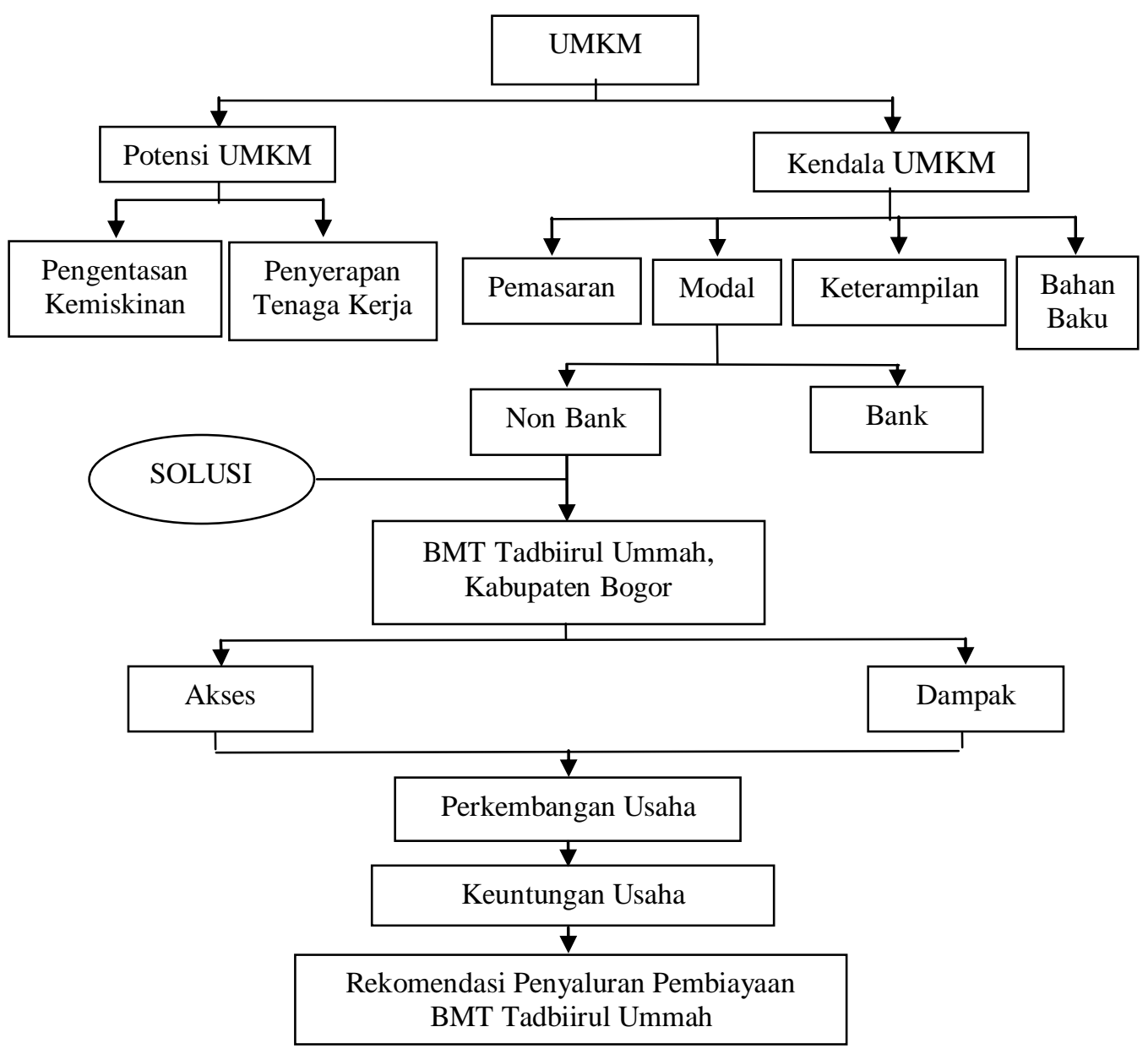

Gambar 1 Kerangka Pemikiran

\section{METODE PENELITIAN}

\subsection{Jenis dan Sumber Data}

Penelitian ini menggunakan data primer dan data sekunder. Data primer diperoleh dari hasil wawancara terhadap 30 unit UMKM yang mendapatkan pembiayaan mikro syariah BMT dan 15 UMKM yang tidak mendapatkan pembiayaan. Data sekunder diperoleh dari BPS Kabupaten Bogor dan Dinas Koperasi UKM Perindustrian dan Perdagangan Kabupaten Bogor.

\subsection{Lokasi dan Waktu Penelitian}

Pemilihan lokasi penelitian dilakukan berdasarkan wilayah pelayanan pembiayaan syariah BMT Tadbiirul Ummah, Kabupaten Bogor. BMT Tadbiirul Ummah dipilih sebagai studi kasus karena BMT ini telah berdiri sejak tahun 1995 dan berada di bawah dampingan Yayasan PERAMU (Pemberdayaan Mustadhafiin) sehingga memiliki jumlah mitra pembiayaan yang cukup banyak dan beragam. Kecamatan Dramaga dan Kecamatan Ciampea dipilih sebagai lokasi penelitian dilandaskan oleh list yang diberikan oleh pihak BMT. Penelitian ini dilakukan pada bulan April hingga Mei 2012. 


\subsection{Metode Pengumpulan Data}

Pengambilan sampel dilakukan dengan menggunakan teknik non probability sampling (non acak) dengan teknik pengambilan datanya dilakukan dengan metode purposive sampling (sengaja), yaitu prosedur memilih sampel berdasarkan pertimbangan karakteristik yang cocok berkaitan dengan anggota contoh yang diperlukan untuk menjawab tujuan penelitian. Pertimbangan dalam pengambilan sampel yaitu berdasarkan tahun penerimaan pembiayaan syariah BMT. Sampel yang diambil dalam penelitian ini sebanyak 45 responden yang terdiri dari 30 responden yang mendapatkan pembiayaan syariah dari BMT pada tahun 2010-2012 dan 15 responden kontrol yang tidak mendapatkan pembiayaan syariah dari BMT yang berlokasi di sekitar wilayah pelayanan pembiayaan BMT.

\subsection{Metode Analisis Data}

\subsubsection{Metode Regresi Logistik}

Faktor-faktor yang mempengaruhi akses UMKM terhadap pembiayaan syariah BMT didapat dengan analisis model logit sebagai berikut:

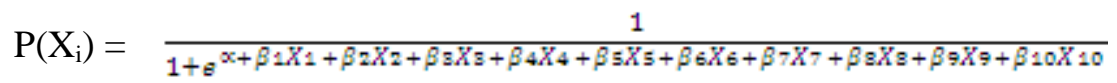

Keterangan:

$\mathrm{P}\left(\mathrm{X}_{\mathrm{i}}\right)=$ Peluang UMKM mengakses pembiayaan syariah BMT $\mathrm{P}(1)=\mathrm{UMKM}$ mengakses pembiayaan syariaah BMT $\mathrm{P}(0)=\mathrm{UMKM}$ tidak mengakses pembiayaan syariah BMT

$\alpha=$ Intersep

$\beta_{\mathrm{i}} \quad=$ Parameter peubah $\mathrm{X}_{\mathrm{i}}$

$\mathrm{X}_{1}=$ Umur (tahun)

$\mathrm{X}_{2}=$ Dummy Jenis Kelamin; $1=$ laki-laki dan $0=$ perempuan

$\mathrm{X}_{3}=$ Lama Pendidikan (tahun)

$\mathrm{X}_{4}=$ Jumlah Anggota Keluarga (orang)

$\mathrm{X}_{5} \quad=$ Dummy Jenis Usaha $; 1=$ perdagangan dan $0=$ lainnya

$\mathrm{X}_{6} \quad=$ Dummy Jenis Usaha $; 1=$ industri manufaktur dan $0=$ lainnya

$\mathrm{X}_{7}=$ Lama Usaha (tahun)

$\mathrm{X}_{8}=$ Omset Usaha (Rp)

$\mathrm{X}_{9} \quad=$ Total Aset $(\mathrm{Rp})$

$\mathrm{X}_{10}=$ Dummy Akses Simpanan; $1=$ memiliki simpanan di BMT dan $0=$ tidak

\subsubsection{Metode Regresi Linear Berganda}

Dampak pembiayaan syariah BMT terhadap perkembangan usaha dengan indikator keuntungan didapat dengan analisis regresi linear berganda Ordinary Least Squared (OLS) sebagai berikut:

$\Delta$ Keuntungan $=\mathrm{f}\left(\right.$ Umur, LP, $\left.\mathrm{DU}_{1}, \mathrm{DU}_{2}, \mathrm{LU}, \mathrm{TK}, \mathrm{ASET}, \mathrm{PS}, \mathrm{FP}, \mathrm{KK}\right)$

Keterangan:

Umur = Umur Responden BMT (tahun)

LP = Lama Pendidikan Responden BMT (tahun)

$\mathrm{DU}_{1} \quad=$ Dummy Jenis Usaha; $1=$ perdagangan dan $0=$ lainnya

$\mathrm{DU}_{2}=$ Dummy Jenis Usaha; $1=$ industri manufaktur dan 0 lainnya 


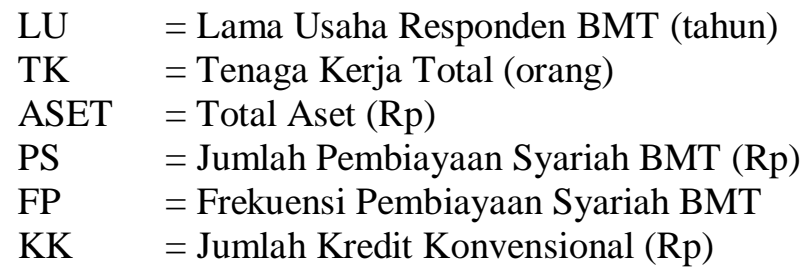

\section{GAMBARAN UMUM BMT TADBIIRUL UMMAH}

BMT Tadbiirul Ummah dibentuk pertama kali pada tanggal 20 Desember 1995 dengan jumlah pendiri (anggota awal koperasi) sebanyak 20 orang dengan total setoran modal awal pendirian koperasi sebesar Rp 9.000.000. Pada awal pendiriannya, BMT Tadbiirul Ummah masih berbentuk Lembaga Pembiayaan Swadaya Masyarakat (LPSM) dan kemudian dibantu oleh Yayasan PERAMU (Pemberdayaan Mustadhafiin) sebagai pendamping dan inisiator. BMT Tadbiirul Ummah berbadan hukum koperasi pada tanggal 8 Agustus 1998 dengan akta pendirian No. 05/BH-KDK/VII/1998.

Produk yang ditawarkan oleh BMT Tadbiirul Ummah terdiri dari produk pemupukan dana dan produk penyaluran dana. Terdapat dua produk pemupukan dana yang dimiliki oleh BMT Tadbiirul Ummah, yaitu TAMAM (Tabungan Mitra Muamalah) dan DERMA (Deposit Mitra Muamalah). Produk penyaluran dana yang BMT Tadbiirul Ummah miliki adalah jual beli dengan akad murabahah, salam dan istishna. Kerja sama atau bagi hasil dengan akad mudharabah dan musyarakah. Sewa dengan akad ijarah dan ijarah muntahiya bittamlik serta gadai syariah dengan akad qardh. Jasa lain yang ditawarkan oleh BMT Tadbiirul Ummah yaitu menerima pembayaran listrik dan telepon online serta konsultasi keuangan usaha dan pengembangan usaha untuk mitra-mitra.

\section{AKSES UMKM TERHADAP PEMBIAYAAN SYARIAH BMT DAN DAMPAKNYA TERHADAP PERKEMBANGAN USAHA, KASUS: BMT TADBIIRUL UMMAH}

\subsection{Karakteristik Responden}

Karakteristik responden BMT dan responden kontrol mengenai usia, lama pendidikan dan jumlah anggota keluarga maupun karakteristik usaha responden mengenai lama usaha dapat dilihat pada Tabel 1.

Responden BMT mayoritas menjalankan usaha di sektor industri pengolahan makanan minuman (53,33 persen). Sedangkan pada responden kontrol sebesar 40 persen responden menekuni sektor perdagangan sebagai bidang usahanya. Besar modal awal usaha responden BMT sebagian besar di bawah 1 juta rupiah (40 persen) dan diantara 1 juta sampai dengan 5 juta rupiah (40 persen). Sedangkan untuk responden kontrol sebesar 60 persen responden membutuhkan modal awal diantara 1 juta sampai dengan 5 juta rupiah. Penguasaan total aset responden kontrol lebih besar daripada responden BMT. Perbedaannya mencapai 49,7 juta rupiah atau sebesar 17,85 persen. Baik responden BMT maupun responden kontrol, penguasaan aset lahan responden lebih besar daripada aset non lahan. Hal ini menunjukkan bahwa sebagian besar aset yang dimiliki bersifat non-liquid. 
Tabel 1. Statistik Deskriptif Karakteristik Responden

\begin{tabular}{|l|c|c|c|c|}
\hline \multicolumn{1}{|c|}{ Variabel } & $\begin{array}{c}\text { Mean } \\
\text { (Rata-rata) }\end{array}$ & $\begin{array}{c}\text { Nilai } \\
\text { Maksimum }\end{array}$ & $\begin{array}{c}\text { Nilai } \\
\text { Minimum }\end{array}$ & $\begin{array}{c}\text { Standar } \\
\text { Deviasi }\end{array}$ \\
\hline \hline Responden BMT & & & & \\
Tingkat Usia & 41,37 & 62 & 22 & 10,02 \\
Lama Pendidikan & 11,133 & 16 & 3 & 3,319 \\
Jumlah Anggota Keluarga & 4,567 & 7 & 2 & 1,305 \\
Lama Usaha & 8,68 & 26 & 1,30 & 6,23 \\
\hline Responden Kontrol & & & & \\
Tingkat Usia & 40,40 & 58 & 32 & 7,02 \\
Lama Pendidikan & 10,60 & 16 & 6 & 2,444 \\
Jumlah Anggota Keluarga & 3,933 & 7 & 3 & 1,223 \\
Lama Usaha & 8,73 & 28 & 1 & 8,75 \\
\hline
\end{tabular}

\subsection{Akses Rumah Tangga Responden pada Lembaga Keuangan}

Akses rumah tangga responden pada lembaga keuangan terdiri dari akses simpanan dan juga akses pinjaman. Akses simpanan rumah tangga responden pada lembaga keuangan dapat dilihat pada Tabel 2. Tabel tersebut menunjukkan bahwa nilai rata-rata akses simpanan responden kontrol pada lembaga keuangan formal (bank) lebih besar daripada responden BMT. Terdapat beberapa alasan pemilihan akses simpanan pada bank, salah satunya adalah untuk kemudahan transaksi usaha seperti transfer, kliring dan pembayaran online yang tidak dimiliki oleh lembaga keuangan semi formal dan informal. Sebanyak 25 responden BMT mempunyai akses tabungan ke BMT, alasan pemilihan lembaga ini karena sistem jemput bola yang ditawarkan dan kemudahan pembayaran angsuran sehingga mengurangi adanya transaction cost.

Tabel 2. Akses Simpanan Responden pada Lembaga Keuangan

\begin{tabular}{|l|c|c|c|c|}
\hline \multirow{2}{*}{\multicolumn{1}{|c}{$\begin{array}{c}\text { Akses } \\
\text { Simpanan }\end{array}$}} & \multicolumn{2}{|c|}{ Responden BMT } & \multicolumn{2}{c|}{ Responden Kontrol } \\
\cline { 2 - 5 } & $\begin{array}{c}\text { Nilai Rata-rata } \\
\text { (Rupiah) }\end{array}$ & Partisipasi & $\begin{array}{c}\text { Nilai Rata-rata } \\
(\text { Rupiah) }\end{array}$ & Partisipasi \\
\hline \hline $\begin{array}{l}\text { Formal } \\
\text { Bank }\end{array}$ & 3.278 .571 & $\mathrm{n}=14(46,67 \%)$ & 9.870 .000 & $\mathrm{n}=10(66,67 \%)$ \\
\hline $\begin{array}{l}\text { Semi Formal } \\
\text { BMT }\end{array}$ & 2.922 .880 & $\mathrm{n}=25(83,33 \%)$ & 1.200 .000 & $\mathrm{n}=5(33,33 \%)$ \\
$\begin{array}{l}\text { Koperasi Simpan } \\
\text { Pinjam }\end{array}$ & 5.000 .000 & $\mathrm{n}=1(3,33 \%)$ & - & - \\
\hline $\begin{array}{l}\text { Informal } \\
\text { Tetangga } \\
\text { Arisan }\end{array}$ & - & - & 200.000 & $\mathrm{n}=1(6,67 \%)$ \\
\hline
\end{tabular}

Tabel 3 menunjukkan akses pinjaman responden kontrol pada lembaga keuangan formal lebih tinggi dibandingkan akses pinjaman responden BMT pada lembaga keuangan formal. Akses rumah tangga responden terhadap pinjaman pada lembaga formal, khususnya bank tidak terlepas dari penguasaan aset yang dimiliki rumah tangga. Hal ini dikarenakan pinjaman pada bank umumnya mengharuskan adanya jaminan atau agunan berupa kepemilikan aset. 
Tabel 3. Akses Pinjaman Responden pada Lembaga Keuangan

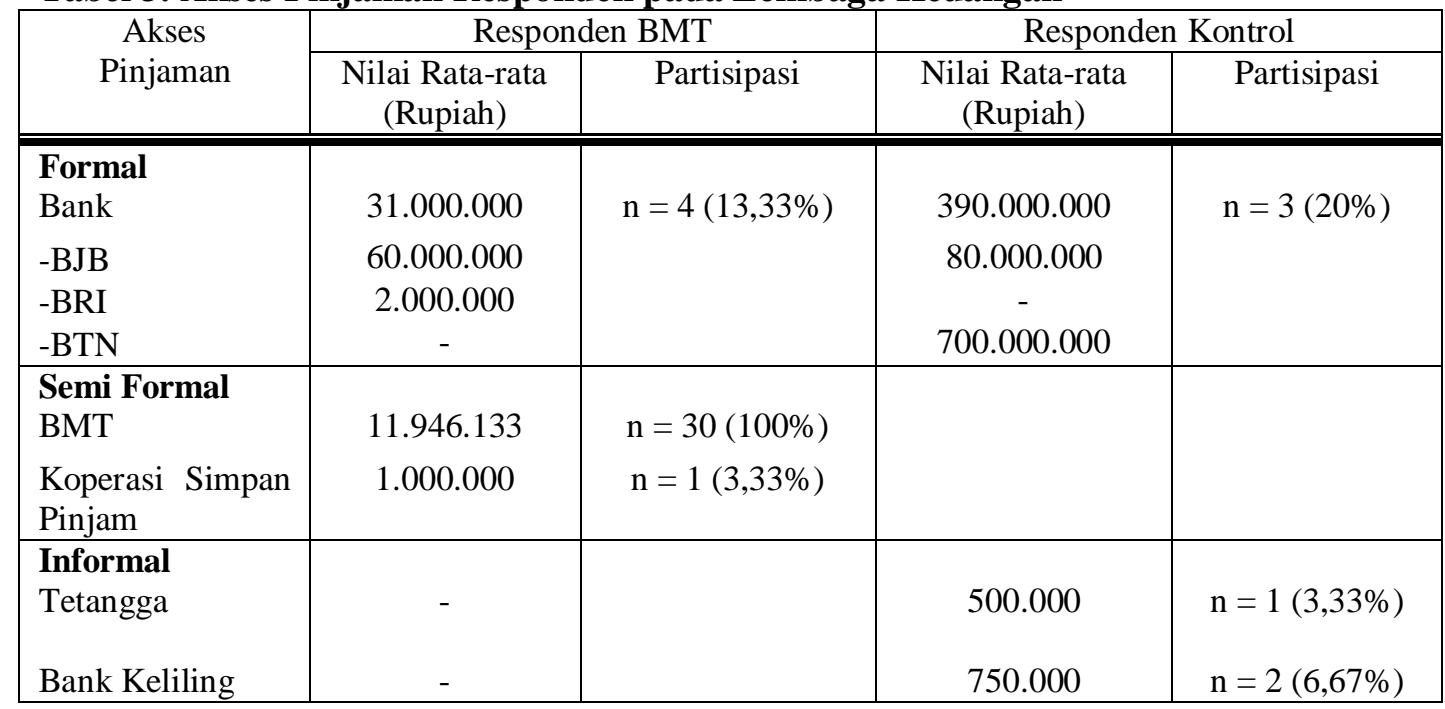

\subsection{Faktor-faktor yang Mempengaruhi Akses UMKM terhadap Pembiayaan Syariah BMT}

Analisis faktor-faktor yang mempengaruhi akses UMKM terhadap pembiayaan syariah BMT dilakukan dengan menggunakan model logit. Hasil model logit disusun dan diuji dengan menggunakan bantuan aplikasi software SPSS 16. Hasil analisis menunjukkan bahwa model dapat mengklasifikasikan secara benar responden yang tidak mengakses pembiayaan syariah dari BMT sebesar 66,7 persen dan sebesar 90 persen yang mengakses pembiayaan syariah dari BMT. Secara keseluruhan model mampu mengklasifikasikan responden dengan mengakses maupun tidak mengkases pembiayaan syariah dari BMT sebesar 82,2 persen. Hasil uji Chi-Square Hosmer and Lemeshow Test menunjukkan nilai Chi-Square sebesar 4,072 dengan p-value 0,771 >0,05 sehingga dapat disimpulkan bahwa model logit secara keseluruhan dapat menjelaskan faktor-faktor yang mempengaruhi akses UMKM terhadap pembiayaan syariah BMT.

Hasil model logit menunjukkan variabel dummy akses simpanan berpengaruh nyata pada taraf 5 persen dan variabel umur, dummy jenis usaha 2 serta omset usaha signifikan pada taraf 10 persen. Variabel dummy akses simpanan mempunyai nilai odds ratio sebesar 17,514 artinya peluang UMKM memiliki akses simpanan BMT untuk mendapatkan pembiayaan syariah dari BMT tersebut adalah 17,514 kali UMKM yang tidak mempunyai akses simpanan pada BMT, ceteris paribus (Tabel 4). 
Tabel 4 Faktor-faktor yang Mempengaruhi Akses UMKM terhadap Pembiayaan Syariah BMT

\begin{tabular}{|l|l|r|l|r|}
\hline \multirow{2}{*}{ No } & \multicolumn{3}{|c|}{ Model Logit } \\
\cline { 2 - 5 } & \multicolumn{1}{|c|}{ Variabel } & Parameter & P-value & Odds Ratio \\
\hline \hline 1. & Konstanta & $-10,471$ & 0,041 & 0,000 \\
\hline 2. & Umur & 0,175 & $0,080^{* * *}$ & 1,191 \\
\hline 3. & Dummy Jenis Kelamin & 0,352 & 0,743 & 1,422 \\
\hline 4. & Lama Pendidikan & 0,179 & 0,375 & 1,195 \\
\hline 5. & Jumlah Anggota Keluarga & 0,548 & 0,242 & 1,730 \\
\hline 6. & Dummy Jenis Usaha 1 & $-0,395$ & 0,762 & 0,673 \\
\hline 7. & Dummy Jenis Usaha 2 & 3,272 & $0,053^{* * *}$ & 26,353 \\
\hline 8. & Lama Usaha & $-0,228$ & 0,105 & 0,796 \\
\hline 9. & Omset Usaha & 0,000 & $0,063^{* * *}$ & 1,000 \\
\hline 10. & Total Aset & 0,000 & 0,408 & 1,000 \\
\hline 11. & Dummy Akses Simpanan & 2,863 & $0,0188^{*}$ & 17,514 \\
\hline
\end{tabular}

Keterangan: $\quad{ }^{*}$ signifikan pada taraf nyata 5 persen

** signifikan pada taraf nyata 10 persen

\subsection{Dampak Pembiayaan Syariah BMT terhadap Perkembangan Usaha UMKM}

Dampak pembiayaan syariah BMT terhadap perkembangan usaha UMKM dianalisis dengan membandingkan nilai keuntungan yang diperoleh oleh responden BMT sebelum dan sesudah memperoleh pembiayaan mikro syariah dari BMT.

Tabel 5. Dampak Pembiayaan Syariah BMT terhadap Keuntungan Usaha

\begin{tabular}{|l|c|c|c|c|c|}
\hline \multirow{2}{*}{ Sektor Usaha } & \multirow{2}{*}{ Frekuensi } & \multicolumn{2}{|c|}{$\begin{array}{c}\text { Keuntungan Rata-rata per } \\
\text { Tahun (Rupiah) }\end{array}$} & \multicolumn{2}{c|}{$\begin{array}{c}\text { Perkembangan Keuntungan } \\
\text { Usaha }\end{array}$} \\
\cline { 3 - 6 } & & $\begin{array}{c}\text { Sebelum } \\
\text { Mendapat } \\
\text { Pembiayaan }\end{array}$ & $\begin{array}{c}\text { Setelah } \\
\text { Mendapat } \\
\text { Pembiayaan }\end{array}$ & $\begin{array}{c}\text { Jumlah } \\
\text { (Rupiah) }\end{array}$ & $\begin{array}{c}\text { Persentase } \\
(\%)\end{array}$ \\
\hline \hline Perdagangan & 7 & 86.160 .000 & 96.445 .714 & 10.285 .714 & 11,94 \\
\hline Jasa & 4 & 76.572 .500 & 92.412 .500 & 15.840 .000 & 20,69 \\
\hline $\begin{array}{l}\text { Industri } \\
\text { Pengolahan } \\
\begin{array}{l}\text { Makanan } \\
\text { Minuman }\end{array}\end{array}$ & 17 & 73.496 .470 & 74.202 .352 & 705.882 & 0,96 \\
\hline Industri Kerajinan & 2 & 107.400 .000 & 107.400 .000 & & \\
\hline Total & 30 & 79.121 .666 & 84.033 .666 & 4.912 .000 & 6,21 \\
\hline
\end{tabular}

Pembiayaan syariah yang diberikan oleh BMT memberikan dampak positif terhadap perkembangan keuntungan usaha sektor perdagangan, jasa dan industri pengolahan makanan minuman (Tabel 5). Sektor jasa mengalami perkembangan keuntungan usaha paling besar. Lokasi usaha responden UMKM jasa (fotocopy dan print) yang strategis menjadi penyebab utama perkembangan keuntungan mengingat kebutuhan mahasiswa yang berada di daerah sekitar lokasi sangat besar. Sektor perdagangan juga mengalami perkembangan keuntungan setelah mendapatkan pembiayaan dari BMT. Hal ini disebabkan oleh omset sektor perdagangan yang bersifat harian (tiap hari) sehingga perputaran uangnya lebih cepat dibandingkan sektor lainnya. Sektor industri kerajinan tidak mengalami perkembangan keuntungan usaha. Hal ini berkaitan dengan penggunaan pembiayaan syariah yang digunakan bukan untuk modal kerja, melainkan untuk investasi membeli tanah.

Untuk melihat pengaruh pembiayaan syariah BMT terhadap perkembangan usaha dilakukan analisis dengan menggunakan model OLS dan diuji signifikansinya dengan menggunakan aplikasi software SPSS 16. Hasil pengolahan data menunjukkan bahwa nilai R-Square dari 
persamaan adalah sebesar 0,624 artinya 62,4 persen keragaman nilai perkembangan keuntungan dapat dijelaskan oleh masing-masing variabel penjelas dalam model. Variabel yang berpengaruh signifikan pada taraf 5 persen adalah lama pendidikan, lama usaha, besarnya pembiayaan syariah BMT dan besarnya kredit konvensional.

Tabel 6. Faktor-faktor yang Mempengaruhi Nilai Perkembangan Keuntungan Usaha

\begin{tabular}{|l|l|r|r|l|r|}
\hline \multirow{2}{*}{ No } & \multicolumn{5}{|c|}{ Model OLS } \\
\cline { 2 - 5 } & \multicolumn{1}{|c|}{ Variabel } & Parameter & t-statistik & \multicolumn{1}{c|}{ P-value } & Elastisitas \\
\hline \hline 1. & Konstanta & $2,658 \mathrm{E} 7$ & 1,752 & 0,096 & \\
\hline 2. & Umur & $-330952,045$ & $-1,378$ & 0,184 & \\
\hline 3. & Lama Pendidikan & $-1,744 \mathrm{E} 6$ & $-2,511$ & $0,021^{*}$ & $-3,918$ \\
\hline 4. & Dummy Jenis Usaha 1 & $9,647 \mathrm{E} 6$ & 1,485 & 0,154 & \\
\hline 5. & Dummy Jenis Usaha 2 & $4,332 \mathrm{E} 6$ & 0,741 & 0,468 & \\
\hline 6. & Lama Usaha & 969561,396 & 2,201 & $0,040^{*}$ & 1,745616 \\
\hline 7. & Total Tenaga Kerja & $1,193 \mathrm{E} 6$ & 1,079 & 0,294 & \\
\hline 8. & Total Aset & $-0,032$ & $-1,512$ & 0,147 & \\
\hline 9. & Pembiayaan Syariah BMT & 0,893 & 4,593 & $0,000^{*}$ & 2,282684 \\
\hline 10. & Frekuensi Pembiayaan & $-6,054 \mathrm{E} 6$ & $-2,772$ & $0,012^{*}$ & $-2,79999$ \\
\hline 11. & Kyariah BMT & 0,349 & 2,153 & $0,044^{*}$ & 0,29128 \\
\hline
\end{tabular}

Keterangan: $\quad{ }^{*}$ signifikan pada taraf nyata 5 persen

Besarnya pembiayaan mikro syariah BMT berpengaruh positif terhadap perubahan keuntungan usaha UMKM dengan koefisien parameter 0,893 dan signifikan pada taraf nyata 5 persen. Ini berarti apabila besarnya pembiayaan mikro syariah BMT meningkat Rp 100 ribu maka perkembangan keuntungan yang diperoleh oleh pelaku usaha akan meningkat sebesar Rp 89.300 rupiah, ceteris paribus. Keuntungan usaha responden secara total mengalami peningkatan sebesar 6,21 persen setelah memperoleh pembiayaan mikro syariah BMT yaitu dari Rp 79,12 juta per tahun menjadi Rp 84,03 juta rupiah per tahun. Namun perkembangan keuntungan yang diperoleh masih cukup kecil.

Nilai elastisitas variabel besar pembiayaan mikro syariah BMT yaitu sebesar 2,283 yang berarti besarnya pembiayaan mikro syariah BMT elastis terhadap besarnya perubahan keuntungan usaha yang diperoleh. Nilai ini memiliki arti apabila besar pembiayaan mikro syariah BMT mengalami peningkatan 1 persen, maka akan meningkatkan perubahan keuntungan usaha sebesar 2,283 persen. Hal ini menunjukkan bahwa adanya pembiayaan mikro syariah BMT memberikan dampak positif terhadap perkembangan usaha UMKM dilihat dari tingkat keuntungannya.

\section{KESIMPULAN DAN SARAN}

\subsection{Kesimpulan}

1. Akses UMKM BMT terhadap perbankan jauh lebih kecil dibandingkan responden kontrol. Sebagian besar UMKM BMT menjadikan BMT sebagai lembaga keuangan komplementer dengan perbankan formal (66,67 persen). Rata-rata jumlah pinjaman dan simpanan responden BMT lebih kecil dari UMKM kontrol yaitu Rp 2,92 juta dan Rp 11,94 juta.

2. Faktor-faktor yang mempengaruhi akses UMKM terhadap pembiayaan mikro syariah dari BMT adalah variabel dummy akses simpanan, umur pengusaha UMKM, dummy jenis usaha 2 (manufaktur), serta omset usaha dengan nilai odds ratio sebesar 17,514, $1,191,26,353$ dan 1,000 . 
3. Pembiayaan mikro syariah dari BMT berdampak positif terhadap perkembangan UMKM. Rata-rata keuntungan usaha mengalami peningkatan sebesar 6,21 persen dari Rp 79,12 juta menjadi Rp 84,03 juta per tahun. Berdasarkan analisis OLS, faktor-faktor yang mempengaruhi nilai perkembangan keuntungan usaha UMKM adalah lama pendidikan, lama usaha, besarnya pembiayaan syariah BMT dan besarnya kredit konvensional.

\subsection{Saran}

Berdasarkan hasil penelitian menunjukkan bahwa pembiayaan yang diberikan oleh BMT mampu meningkatkan keuntungan usaha, namun peningkatan yang diperoleh masih cukup kecil. Hal ini dikarenakan pembiayaan yang disalurkan untuk modal kerja dan investasi relatif kecil. Peningkatan modal BMT melalui tabungan dan lainnya diharapkan agar dapat meningkatkan jumlah penyaluran pembiayaan mikro syariah pada UMKM yang unbakable.

\section{Daftar Pustaka}

Adi, M Kwartono. 2007. Analisis Usaha Kecil dan Menengah. Andi: Yogyakarta.

Aryati. 2006. Analisis Permintaan dan Efektivitas Pembiayaan Usaha Kecil Pada Lembaga Keuangan Mikro Syariah (Studi Kasus KBMT Khidmatul Ummah, Kecamatan Cibungbulang, Bogor). [Skripsi]. Ilmu Ekonomi. Fakultas Ekonomi dan Manajemen. Institut Pertanian Bogor. Bogor.

Badan Pusat Statistik. 2011. Data Statistik BPS. Badan Pusat Statistik. Jakarta

Hidayati, A. 2009. Analisis Faktor-faktor yang Mempengaruhi permintaan Pembiayaan Lembaga Keuangan Syariah (Studi Kasus pada BMT Safinah Klaten). [Skripsi]. Universitas Negeri Sebelas Maret. Surakarta.

Kementrian Negara Koperasi dan UMKM Republik Indonesia. 2011. Indikator Makro Usaha Kecil dan Menengah. Jakarta.

Kurnialestari. 2007. Analisis Tingkat Kesehatan dan Faktor-Faktor yang Memengaruhi Pembiayaan Mitra Koperasi Baitul Maal wat Tamwil (KBMT) Ibbadurrahman. [Skripsi]. Fakultas Pertanian Institut Pertanian Bogor. Bogor.

Krisnamurti, B. 2005. Pengembangan Keuangan Mikro bagi Pembangunan Indonesia Media Informasi Bank Perkreditan Rakyat. Edisi IV Maret 2005. Jakarta.

Oktavi, Sholikha. 2009. Analisis Faktor-faktor yang Memengaruhi Pengambilan Pembiayaan dan Efektivitas Pembiayaan Usaha Kecil pada Lembaga Keuangan Mikro Syariah (Studi Kasus: KJKS Bina Umat Sejahtera, Lasem, Jawa Tengah). [Skripsi]. Ilmu Ekonomi. Fakultas Ekonomi dan Manajemen. Institut Pertanian Bogor. Bogor.

Rizky, A. 2007. BMT Fakta dan Prospek Baitul Maal wat Tamwil. UCY Press, Yogyakarta.

Supriatna, A. 2008. Aksesibilitas Petani Kecil pada Sumber Kredit Pertanian di Tingkat Desa: Studi Kasus Petani Padi di Nusa Tenggara Barat. Balai Besar Pengkajian dan Pengembangan Teknologi Pertanian Bogor, Bogor. http://ejournal.unud.ac.id [1 Juni 2012].

Walpole, E.R. 1993. Pengantar Statistika. Edisi Ke-3. PT Gramedia Pustaka Utama. Jakarta.

Widyaningrum, N. 2002. Model Pembiayaan BMT dan Dampaknya bagi Pengusaha Kecil : Studi Kasus BMT dampingan Yayasan Peramu. Yayasan Aka Tiga, Bandung. 